\title{
correspondence
}

\section{UNESCO and Trieste}

SiR,-Your leader of November 8 was critical of the line you thought the United Kingdom would be taking on the question of the International Centre for Theoretical Physics, Trieste, at the recent 18th General Conference of UNESCO, and attributed this probable attitude largely to Sir Harold Thompson personally.

Now that the General Conference is over, we would like to put on record that Sir Harold Thompson, as the British spokesman in the Science Commission of the General Conference, was representing the views of the Royal Society UNESCO Committee, endorsed by Her Majesty's Government. Britain was not critical of the achievement of the ICTP: indeed the British delegate praised the Centre and its Director. Nor was the United Kingdom delegation seeking the withdrawal of UNESCO funds to the ICTP in the forthcoming biennium; it voted for the budget for the basic sciences, including the full proposed provision for the Trieste Centre in 1975 and 1976.

Along with several other Member States, however, the United Kingdom delegation at the same time supported a resolution, passed unanimously at the 94th Session of the UNESCO Executive Board in May of this year, which stated that: -

"(The Executive Board) ... Takes the view that Unesco's continued support to the International Centre for Theoretical Physics, Trieste, for the years 1975-76, is acceptable, but is of the opinion that Unesco's relations with and subvention to the Centre should be reexamined carefully in the light of Unesco's total support to basic sciences."

\section{C. MARTIN \\ A. B. Cozens}

Royal Society UNESCO Committee, Ministry of Overseas Development, London, $U K$

\section{Irrationalism and science}

SiR,- I agree wholeheartedly with the comments of Martin Raff (Nature, December 6). I have been to a number of good conjuring shows in my time and I have invariably found that in a high proportion of the tricks I am not only unable to see how they were done, but I have been unable to understand how they could possibly have been done without an entirely unreasonable amount of joint conspiracy with mem- bers of the audience. In no case has this led me to believe that novel mental powers were required.

If we were to believe that $\mathrm{Mr}$ Geller's achievements went beyond our scientific understanding in the ways that his supporters suggest, there are some very uncomfortable corollaries which have apparently been unnoticed. For example, if he can bend a fork from a distance he could presumably be able to do the smaller mechanical task of putting a kink in an artery.

I am not imputing any undesirable behaviour to Uri Geller, but if other less upright exponents of his art should appear, could they be trusted not to try this on people who were in their way? We are better now at looking for reliable evidence for such things than were the past believers in black magic or present believers in Juju, and could investigate properly the statistics of unexpected coronary thromboses or strokes among the known enemies in the past of suspected people. Having found a number of suspects for which the probability of $\mathrm{chance}$ gave $P<0.001$, we should still have around one in a thousand who would be unjustly indicated as guilty. For further tests the extensive mediaeval literature on witchoraft should be re-examined.

I seem to remember a technique which consisted of throwing the suspect into a pond; if she sank she was innocent and received a Christian burial while if she floated she was dispatched with a silver bullet and buried with a stake through her heart at cross roads.

Since I think the whole suggestion of super-normal powers is nonsense, I am not myself bothered, but those who take the opposite view might well be needing to consider just what legislation would be necessary for dealing with a witch if their case should ever be proved.

Department of Physics,

University of Birmingham, $U K$

Strong, attractive, vain ...

Sir, - The recent contribution by Gribbin' suggests, inter alia, that there may be a significance in the titular characteristics of the Leo sub-group on the Nature editorial staff. This possibility of significance is given weight by McIntosh, who writes of those born under Leo: "The Sun rulership gives him a strong attractive personality and makes it easy for him to command loyalty from athers. These qualities make him a natural leader, and the sign has long been associated with kings and potentates"2. It should perhaps also be mentioned that, according to the same source, "The faults that sometimes afflict the Leonian are vanity, pomposity and greed for power".

In view of the fit between sub-group attainment and expectations, it is regrettable that further research, carried out in an institution similar to the one in which Gribbin works, has shown that the Pisces hypathesis does not hold water ${ }^{3}$.

New Scientist,

London, UK

' Gribbin, J., Nature, 252, 534 (1974).

2 Mclntosh, C., The Astrologers and their Creed, 130 (Hutchinson, London, 1969).

${ }^{3}$ New Scientist, 64, 880 (1974).

\section{Ghost authors}

SiR,-Ghost authors (Nature, December 6) are no new phenomenon. A good many years ago a paper by the late Professor Martin Rushton was published, giving after the author's name his qualification M.A.Cantab. Subsequently this was mistaken for a second author, and the reference "Rushton and Cantab" was a standing joke among dental research workers for some years. It found its way into at least one textbook.

Dorothy A. LunT Glasgow Dental Hospital and School, Glasgow, UK

\section{Nullius in verba}

SiR,--R. B. Cater's complaint (Nature, November 29 ) that $70.4 \%$ of all inquiries for a reprint spelt his name wrongly, is not as bad as he makes out.

It is a firm principle in science that the worth of any man's work is independent of that man's non-intellectual attributes, such as mere name. Far from displaying a lack of observational powers I would say that they are verifying the principle (and the motto of the Royal Society)-nullius in verbaon the words of no man.

Dr Cater would have had more cause for complaint if either (a) his work was disregarded because he was thought to be insignificant or (b) his work was accepted because his father was thought to have been a good scientist.

The University, Colin Price

Hull, UK 